
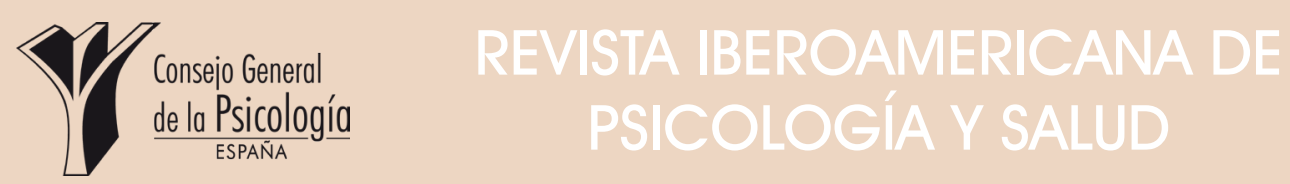

Revista Oficial de la Federación Iberoamericana de Asociaciones de Psicología (FIAP)

[Official Journal of the Latin-American Federation of Psychological Associations]

\title{
Self-concept and emotional well-being in patients with breast cancer
}

\section{Sheila Pintado*}

Universidad de las Américas Puebla, San Andrés Cholula, México.

- Received: 24 - August - 2016 - Accepted: 8 - March - 2017 . Avaliable online: 25 - April - 2017

ABSTRACT. Self-concept is a multi-dimensional factor that includes variables as body image, self-esteem and self-efficacy. Patients suffering from breast cancer present alterations in their self-concept and it affects the emotional well-being. The aim of this study is to analyze the relationship between variables of self-concept and emotional well-being.

Methods: The sample consisted in 131 women diagnosed with breast cancer. The questionnaires used were HADS, RSES, BIS and a monoitem based in Bandura's theory. Once the data was collected, they were coded in a database and subsequently analyzed using SPSS and for the structural model was used EQS 6.1 program.

Results: Emotional well-being is influenced by alterations on self-concept. Patients who had more alterations in body image and less self-esteem and self-efficacy, had higher levels of anxiety and depression. Moreover, self-esteem and self-efficacy were mediating the relationship between body image and emotional well-being.

Conclusions: This study provides evidence for mediating variables of self-concept that affect the emotional well-being of breast cancer patients and they can explain the symptoms of depression and anxiety.

KEYWORDS: Breast cancer; Body image; Well-being; Path analysis; Self-concept.

\section{Auto-concepto y bienestar emocional en pacientes con cáncer de mama.}

RESUMEN. El auto-concepto es un factor multi-dimensional que incluye la imagen corporal, la autoestima y la auto-eficacia. Los pacientes que padecen cáncer de mama presentan alteraciones en su auto-concepto y éste afecta al bienestar emocional. El propósito de este estudio es analizar la relación entre las variables del auto-concepto y el bienestar emocional.

Método: la muestra de estudio consistió en 131 mujeres diagnosticadas con cáncer de mama. Los cuestionarios utilizados fueron HADS, RSES, BIS y un mono-ítem basado en la teoría de Bandura. Una vez los datos fueron recogidos, fueron codificados y analizados mediante el SPSS y para el modelo estructural se utilizó el programa EQS 6.1.

Resultados: el bienestar emocional está influido por las alteraciones en el auto-concepto. Los pacientes que tenían mayores alteraciones en su imagen corporal y menor auto-estima y auto-eficacia, tenían mayores niveles de síntomas de ansiedad y depresión. Además la auto-estima y la auto-valía estaban mediando la relación entre la imagen corporal y el bienestar emocional.

Conclusiones: este estudio muestra evidencia de las variables mediadoras del auto-concepto que afectan el bienestar emocional de las pacientes con cáncer de mama y que pueden explicar los síntomas de la depresión y ansiedad.

PALABRAS CLAVE: Cáncer de mama; Imagen corporal; Bienestar emocional; Path analysis; Auto-concepto.

*Correspondence: Sheila Pintado.

Ex Hacienda Sta Catarina Mártir, Universidad de las Américas Puebla.

Postcode: 72810, San Andrés Cholula (México).

E-mail:maria.pintado@udlap.mx

(C) 2017 Sociedad Universitaria de Investigación en Psicología y Salud. Published by Conseio General de Colegios Oficiales de Psicólogos, Spain (http://creativecommons. org/licencias/by-nc-nd/4.0/)
Breast cancer is the most frequent neoplasm in women and it has a negative impact on selfconcept and the emotional well-being of the patients who suffer it (Al-Ghazal, Fallowfield \& Blamey, 2000; Arora et al., 2001; SchmidBüchi, Halfens, Dassen \& van den Borne, 2011 ; Schmid-Büchi, Halfens, Müller, Dassen \& van 
den Borne, 2013). Moreover, these alterations in self-concept could affect the emotional wellbeing.

Normally, low levels in emotional well-being in patients with breast cancer are understood in relation to high levels of anxiety and depression (Carver et al., 2005; Epping-Jordan, 1999; cited by Compas \& Luecken, 2002; Hanson-Frost et al., 2000; Ganz et al., 2002; Meyerowitz, 1980).

The study of self-concept in breast cancer patients has been studied some years ago. Despite this, it is difficult to find accordance and unanimity to define self-concept. However, there is an agreement to consider it as a multidimensional construct (Peralta \& Sánchez, 2003).

Shavelson and Bolus (1992), defined selfconcept as a group of perceptions or references that the person has about him or herself and it includes judgments about behaviors, abilities and external appearance. In this sense, selfconcept can include the body image, self-esteem and self-efficacy. Although these concepts are different, they are related to.

Starting with body image, this refers to the perceptions and judgements that one has about oneself, one's self-concept. Body image is a complex concept that includes both the perception we have of the body, such as the boundaries of the movement and the subjective experience of attitudes, values we have and how we behave when we enter in contact with our environment (Raich, 2000).

Breast cancer is one of disease that most affects the corporal identities of its suffers, and it implies an adaptation to changes with their body image, feelings and attitudes (Andersen \& LeGrand, 1991 ; Bloom, Stewart, Chang \& Banks, 2004; Brunet, Sabiston \& Burke, 2013; CoussonGélie, Bruchon-Schweitzer, Dilhuydy \& Jutand, 2007; Lemieux, Maunsell \& Provencher, 2008; Petronis, Carver, Antoni \&Weiss, 2003; Ussher, Perz \&Gilbert, 2012). Add to this, the possible side effects, of alopecia, skin problems, loss of fertility and the premature onset of menopausal symptoms and the consequences for sufferers are ongoing (Carver et al., 2005; Choi et al., 2015; Fertig, 1997; Ganz et al., 2002; Hanson Frost et al., 2000; Poinsot, Brédart, This, De La Rochefordière \& Dolbeault, 2005; Schover et al., 1995; Tish, 2006; Zhao et al., 2001).

A disturbance of one's body image can include dissatisfaction with their appearance, perception about loss of femininity, wherein patients avoid seeing themselves naked and a consequently have a low sense of self-attraction (Fobair et al., 2006). Consequently, emotional well-being is affected and this disruption in the normal psychological function is related to the alterations in the body image (Anillo, 2000; Avis, Crawford \& Manuel, 2004; Begovic-Juhant, Chmielewski, Iwuagwu \& Chapman , 2012; Brandberg et al., 2008; Chang et al., 2014; Collins et al., 2011 ; Falk, Reinertsen, Nesvold, Fossa \& Dahl, 2010; Fobair et al., 2006; Helms, O'Hea \& Corso, 2008; . McClelland, Holland \& Griggs, 2015; Przezdciecki et al., 2013). However, some authors have demonstrated that there are variables mediating the relationship between body image and emotional wellbeing (Miller, Schnur, Weinberger-Litman \& Montgomery, 2014; Przezdziecki et al., 2013). These findings suggest that the alterations in body image are indirectly associated with distress through determined variables.

Self-esteem, as defined by Rosenberg (1965) encompasses the attitudes or feelings about oneself. One recent definition of selfesteem emphasizes that it is the affective or evaluative component of the self-concept (Leary \& Baumeister, 2000). Within patients affected by breast cancer levels of self-esteem have a close relationship with the emotional well-being and the body image (Bertero, 2002; Wong-Kim \& Bloom, 2005).

Similarly, self-efficacy is defined as having positive thoughts about one's capacity to achieve something, take control and to have the skills necessaries to do it (Han et al., 2005; Lam \& Fielding, 2006). It can also be understood as determining the action of people (Bandura, 1982). Self-efficacy is related to with a better psychological adjustment, self-esteem, wellbeing and adaptation to chronic illness (Compas y Luecken, 2002; Han et al., 2005; Karademas et al., 2007; Lam \& Fielding, 2006; Rogers et al., 2008; Taylor et al., 1984; Zachariae et al., 2003). In an interesting study, results showed that self-efficacy could moderate the relationship between body image disturbances and cancer screening behaviors (Ridolfi \& Crowther, 2013).

In addition, the type of surgery is the variable most studied in relation to the psychological adjustment of breast cancer patients. In this sense, the majority of studies show that radical, 
more invasive surgery, has a negative impact on the emotional well-being (Al-Ghazal, Fallowfield \& Blamey, 2000; Avis, Crawford \& Manuel, 2004; Skrzypulec, Tobor, Drosdzol \& Nowosielski, 2007; Yurek, Farrar \& Andersen, 2000). However, not at all of the studies have found a direct relationship between them (Ganz et al., 2002; Schover et al., 1995; Wong-Kim \& Bloom, 2005).

As the above review demonstrates, there are a variables of self-concept involved in the emotional well-being of patients with breast cancer. But, do they have a direct relationship with the emotional well-being? Or, are there some variables of self-concept mediating these relations?

To date, there are very few scientific studies that have tried to create explanatory models that can observe and predict the variables of selfconcept that affect the emotional well-being of cancer patients. Therefore, the objective of this study is to develop a predictive model of emotional well-being in patients with breast cancer using a structural model of path analysis using the variables more investigated in the selfconcept of breast cancer patients.

\section{METHOD}

\section{- PARTICIPANTS}

The sample of participants was formed by 131 women diagnosed with breast cancer and recruited from four public hospitals in Spain. Criterial of inclusion were to be over 18 years of age, diagnosed with breast cancer in the state I or II and to have completed an active treatment as chemotherapy, radiotherapy or hormone therapy.

\section{MEASURES}

\section{- EMOTIONAL WELL-BEING}

The Hospital Anxiety and Depression Scale (HADS; Zigmond \& Snaith, 1983) was used to evaluate emotional wellbeing. A self-administered questionnaire of 14 items, consisting of two 7-item subscales, one for anxiety (odd items) and a depression (pair items) was given to them. It is rated on a Likert scale of 4 points (range $0-3$ ). The breakpoints of the subscales are: 0-7: normal, 8-10: doubtful, 11 or more, pathological. In the present study, the reliability was high for both subscales (.86 for Anxiety and .88 for Depression).

\section{- BODY IMAGE}

The Body Scale Inventory (BSI; Hopwood, Fletcher, Lee \& AlGhazal, 2001) was used to assess body image. It is a questionnaire consisting of 10 items with Likert response format with four alternatives, ranging from 0 to 3 . The maximum score is 30 and more punctuation indicates more alterations in the body image. The original scale has a good reliability of .93. In the current study, the reliability was .95 .

\section{- SELF-ESTEEM}

The Rosenberg Self-Esteem Scale (RSES; Rosenberg, 1965) was used to assess selfesteem. This is one of the most used scales in the assessment of self-esteem, which consists of 10 items with Likert response format with four alternatives, ranging from 1 to 4 . Internal consistency measured with Cronbach's alpha is between .76 and .87. In the present study, reliability was .89 .

\section{- SELF-EFFICACY}

Following the guidelines of Bandura (1982), self-efficacy was measured by a mono-item through the question: "Are you able to cope with your situation? (not at all: 0 - completely: 10).

\section{- PROCEDURE}

First of all, permissions and favorable reports from Ethic Committee about human investigation in each hospital were got, in accordance with the 1964 Helsinki declaration. After, patients were recruited following the eligible criteria and by disposition from the outpatient Oncology Unit within a public hospitals. The type of sampling was non-probabilistic by disposition. They were informed about the investigation by the researcher (a PhD expert in clinical and health psychology) and after informed consents were accepted and signed by patients, they were interviewed.

The data collection process consisted of giving printed tests to patients who consented to 
a document where anonymity and confidentiality would be ensured in a single moment of evaluation. All this time, the researcher was with the patients supervising and clarifying some questions about the items.

Once the data was collected, it was coded in a database and subsequently analyzed using SPSS 17. For the structural model the EQS 6.1 program was used.

The mathematical model used includes covariance and major structured models, multiple regression, simultaneous equations, and structural relationships between variables, etc.

This is a descriptive study and the type of design of the research is correlational, and although it is a study at a single moment in time (without intervention) it cannot establish causeconsequence. Nonetheless, it does allow us to quantify the relationships between key variables that explain the adaptation process to the illness.
The structural model can provide a general vision and a first approximation to identify relationships with the variables of the study (Hox \& Bechger, 1998).

\section{RESULTS}

\section{- SAMPLE CHARACTERISTICS}

Participants were Spanish women with a mean age of 55.12 years (SD. 9.91). They were diagnosed with breast cancer and the type of surgery was radical mastectomy in the $43.3 \%$ and breast conserving surgery in the $55.7 \%$. The majority of them was married (68.7\%), with primary education $(45.8 \%)$ and having received a complete adjuvant treatment (61.4\%). Relevant demographic data are provided in Table 1.

\begin{tabular}{|c|c|c|}
\hline VARIABLE & $\%$ or Mean & Range (SD) \\
\hline \multicolumn{3}{|l|}{ MARITAL STATUS } \\
\hline Married & $68.7(100)$ & \\
\hline Divorced / separated & $10.7(10)$ & \\
\hline Single & $11.4(12)$ & \\
\hline Widow & $9.2(9)$ & \\
\hline \multicolumn{3}{|l|}{ EDUCATION LEVEL } \\
\hline Primary & $45.8(60)$ & \\
\hline Secondary & $30.5(40)$ & \\
\hline Bachelor & $22.9(30)$ & \\
\hline Master & $0.8(1)$ & \\
\hline TIME SINCE DIAGNOSTIC & 4.79 years & 3.745 \\
\hline \multicolumn{3}{|l|}{ TYPE OF SURGERY } \\
\hline Mastectomy & $44.3(58)$ & \\
\hline Breast conserving surgery & $55.7(73)$ & \\
\hline \multicolumn{3}{|l|}{ ADJUVANT TREATMENT } \\
\hline Chemotherapy & $4.6(6)$ & \\
\hline Radiation & $7.9(10)$ & \\
\hline Hormonal treatment & $4.6(6)$ & \\
\hline Chemiotherapy+radiation & $21.5(21)$ & \\
\hline Chemotherapy+radiotherapy+hormonal treatment & $61.4(81)$ & \\
\hline
\end{tabular}




\section{- CORRELATION AND COMPARATIVE ANALYSES}

On the one hand, results showed that Depression had a positive and high correlation with Anxiety $(r=.671 ; p<.001)$, negative and high with Self-esteem $(r=-.640 ; p<.001)$, positive and moderate with Body image $(r=.398 ; p<.001)$, and negative and high with Self-efficacy $(r=-.557 ; p<.001)$.

On the other hand, Anxiety had negative and high relationship with Self-esteem $(r=-.539 ; p<.001)$, positive and moderate with Body image $(r=.302 ; p<.001)$, and negative and moderate with Self-efficacy $(r=-.394$; $p<.001)$.

Finally, the type of surgery that has been applied to patients had a significant relationship with emotional well-being and the components of self-concept. In this regard, it is noted that a radical mastectomy was related to increased depression $\left(F_{129}=6.693 ; p<.01\right)$, alterations with body image $\left(F_{129}=29.940 ; p<.001\right)$ and poor self-esteem and self-efficacy $\left(F_{129}=4.548\right.$; $p<.05$ and $F_{129}=7.250 ; p<.05$, respectively). However, the type of surgery was unrelated to anxiety $\left(F_{129}=1.105 ; p=.295\right)$.

\section{- MEDIATION ANALYSES}

The model used was a structural model of path analysis with observable variables, which aims to assess the predictive ability of the variables analyzed in emotional well-being.

The variables were anxiety, depression, selfesteem, body image and self-efficacy.

Results showed a coefficient of Mardia of 14.8086, and 6.0226 normalized as $p(p+2)$ where $p$ is the observable variable, indicating that the present model data was within the normal range. And the overall fit indices were: FIT $=$ $.904 ; \mathrm{CFI}=0.945 ; \mathrm{GFI}=.948 ; \mathrm{RMR}=.065$ and RMSEA $=.091$, indicating that the model had strength and good coefficients to be used as path analysis. Moreover, model variables kept a significant relationships between them, $p<.05$ significance level and 95\% confidence level.

As it can be seen in Figure 1, depression was negatively related to the variables of selfesteem, and self-efficacy. Thus, women with low self-esteem and a poor sense of self-efficacy, presented higher levels of depression. In addition, body image had indirect effects on depression; women with major alterations in their body image presented higher levels of depression.

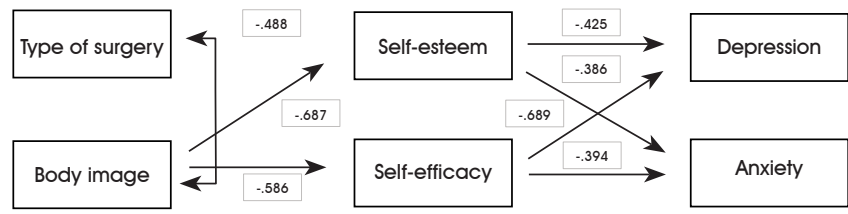

Figura 1. Mediation model.

Moreover, anxiety maintained a significant and negative relationship with self-esteem and self-efficacy. In this sense, women with low selfesteem and low self-efficacy had higher levels of anxiety. And, like depression, anxiety was influenced by an indirect effect of the body image; women with major alterations in body image had higher anxiety levels.

Self-esteem was explained by body image. Patients with minor alteration of their body image had higher levels of self-esteem.

Finally, self-efficacy was explained by body image too; women with a less altered body image had greater level of self-efficacy.

Body image was negatively related to the type of surgery; thus, women with a radical mastectomy had higher perceived changes in body image.

The resulting model was able to explain $56.7 \%$ of Depression, $42.3 \%$ of Anxiety, $20.4 \%$ of Self-Efficacy, and $14.2 \%$ of Self-Esteem.

\section{DISCUSSION}

In this investigation, relationships between variables of self-concept and the emotional well-being of cancer patients were observed.

Results showed that emotional well-being is influenced by self-esteem, body image and selfefficacy. Thus, these results are consistent with research that argue that patients with a good body image and increased self-esteem and self-efficacy have lower levels of anxiety and depression, as shown in the literature (Al Ghazal et al., 2000; Avis et al., 2004; Berterö, 2002; Compas \& Luecken, 2002; Fobair et al., 2006; Graziottin \& Rovei, 2007; Han et al., 2005; Karademas et al., 2007; Lam \& Fielding, 2006; Petronis et al., 2003; Poinsot et al., 2005; Taylor et al., 1984; Wong-Kim \& Bloom, 2005; Yurek et al., 2000; Zachariae et al., 2003). 
However, body image does not have a direct relationship with emotional well-being. The relationship between body image and emotional well-being is mediated by self-esteem and self-efficacy.

This is a new contribution to understand how emotional well-being on breast cancer patients is damaged. Normally, results of investigations have demonstrated a direct relationship between body image and well-being; but the present investigation shows that there are variables mediating this connection, as some current authors (Miller et al., 2014; Przezdziecki et al., 2013; Ridolfi \& Crowther, 2013).

In addition, results showed that women who received a radical mastectomy had higher levels of depression, in accordance with the previous studies analyzed (Al-Ghazal et al., 2000 Avis et al., 2004; Skrzypulec et al., 2007; Yurek et al., 2000). However, we found similar levels of anxiety in both groups, as the work of other authors indicates (Ganz et al., 2002; Schover et al., 1995; Wong-Kim \& Bloom, 2005).

But, the main contribution of this study is that, until the type of surgery and depression are related to, this relationship has an indirect effect. That is, the type of surgery affects the body image; and the alterations of body image affect the self-esteem and the self-efficacy. And all these alterations contribute a poor emotional well-being and to increase symptoms of anxiety and depression.

One limitation of this study is having a smaII and homogeneous sample in terms of age, the majority of who were between the ages of 45 and 61 . This limits the findings in terms of being able to compare age with other variables related to self-concept and emotional well-being.

Regarding the assessment of emotional issues, patient's emotional well-being has been widely studied. However, their evaluation is not specific to breast cancer. Therefore, it was given great importance to take into account the variables analyzed in this work, so as to delve into the specifics of emotional well-being of patients with breast cancer. This importance is further emphasized given than the majority of studies into body image are based on eating disorders or dysmorphic rather than on patients with breast cancer.

Based on these results, and taking into account the needs of women with breast cancer, it is important, for further research, to increase the sample of participants including diverse age groups and to create scales that measure the emotional well-being and self-concept of patients that take into account the various characteristics of this disease.

Concluding, emotional well-being on breast cancer patients is related to the alterations in the self-concept. However, not at all variables involved on self-concept have a direct relationship with the emotional-wellbeing. The present study contributes to our understanding of how body image affects the emotional well-being by intermediary variables of self-concept, as self-esteem and self-efficacy.

\section{- Conflict of interest}

The authors declare no conflict of interest.

\section{REFERENCES}

Al-Ghazal, S., Fallowfield, L., \& Blamey, R. (2000). Comparison of psychological aspects and patient satisfaction following breast conserving surgery, simple mastectomy and breast reconstruction. European Journal of Cancer, 36, 1938-1943. doi: 10.1016/50959-8049(00)00197-0

Andersen, B., \& LeGrand, J. (1991). Body image for women: Conceptualization, assessment, and a test of its importance to sexual dysfunction and medical illness. The Journal of Sex Research, 28, 457-477. doi: 10.1080/00224499109551619

Anillo, L. (2000). Sexual life after breast cancer. Journal of Sex \& Marital Therapy, 26, 241 -248. doi: 10.1080/00926230050084632

Arora, N., Gustafson, D., Hawkins, R., McTavish, F., Cella, D., Pingree, S., ...\& Mahvi, D. (2001). Impact of surgery and chemotherapy on the quality of life of younger women with breast carcinoma: A prospective study. Cancer, 92, 1288-1298. doi:10.1002/1097$0142(20010901) 92: 5<1288::$ AID . CNCR1 $1450>3.0 . \mathrm{CO} ; 2-\mathrm{E}$

Avis, N., Crawford, S., \& Manuel, J. (2004). Psychosocial problems among younger women with breast cancer. Psycho-Oncology, 13, 295-308. doi: 10.1002/ pon.744

Bandura, A. (1982). Self-efficacy mechanism in human agency. American Psychologist, 37, 122-147. doi: 10.1037/0003-066X.37.2.122

Begovic-Juhant, A., Chmielewski, A., Iwuagwu, S., \& Chapman, L. A. Impact of body image on depression and quality of life among women with breast cancer. Journal of Psychosocial Oncology, 30, 446- 
460. doi:10.1080/07347332.2012.684856

Berterö, C. (2002). Affected self-respect and self-value: The impact of breast cancer treatment on self-esteem and QoL. Psycho-Oncology, 11, 356-364. doi: 10.1002/pon.577

Bloom, J., Stewart, S., Chang, S., \& Banks, P. (2004). Then and now: Quality of life of young breast cancer survivors. Psycho-Oncology, 13, 147-160. doi: 10.1002/pon.794

Brandberg, Y., Sandelin, K., Erikson, S., Jurell, G., Liljegren, A., Lindblom, A., ...\& Arver, B. (2008). Psychological reactions, quality of life, and body image after bilateral prophylactic mastectomy in women at high risk for breast cancer: A prospective 1 -year followup study. Journal of Clinical Oncology, 26, 39433949. doi: 10.1200/JCO.2007.13.9568.

Brunet, J., Sabiston, C., \& Burke, S. (2013). Surviving breast cancer: Women's experiences with their changed bodies. Body Image, 10, 344-351. doi: 10.1016/i.bodyim.2013.02.002

Carver, C., Smith, R., Antoni, M., Petronis, V., Weiss, S., \& Derhagopian, R. (2005). Optimistic personality and psychosocial well-being during treatment predict psychosocial well-being among long-term survivors of breast cancer. Health Psychology, 24, 508-516. doi: 10.1037/0278-6133.24.5.508

Chang, O., Choi, E., Kim, I., Nam, S., Lee, J., Lee, S., ...\& Cho, J. (2014). Association between socioeconomic status and altered appearance distress, body image, and quality of life among breast cancer patients. Asian Pacific Journal of Cancer Prevention, 15, 8607-8612. doi: 10.7314/APJCP.2014.15.20.8607

Choi, E., Kim, I., Chang, O., Kang, D., Nam, S. Lee, J., ...\& Cho, J. (2014). Impact of chemotherapyinduced alopecia distress on body image, psychosocial well-being, and depression in breast cancer patients. Psycho-Oncology, 23, 1103-1110. doi: 10.1002/ pon.3531

Collins, K., Liv, Y., Schootman, M., Aft, R., Yan, Y., Dean, G., ...\& Jeffe, D. (2011). Effects of breast cancer surgery and surgical side effects on body image over time. Breast Cancer Research and Treatment, 126, 167-176. doi: 10.1007/s10549-010-1077-7

Compas, B., \& Luecken, L. (2002).Psychological adjustment to breast cancer. Current Directions in Psychological Science, 11, 111-114. Retrieved from http://journals.sagepub.com/doi/pdf/10.1111/1467. 8721.00180

Cousson-Gélie, F., Bruchon-Schweitzer, M., Dilhuydy, J., \& Jutand, M. (2007). Do anxiety, body image, social support and coping strategies predict survival in breast can-cer? A ten year follow-up study.
Psychosomatics, 48, 211-216. doi: 10.1176/appi. psy.48.3.211

Falk, C.A., Reinertsen, K.V., Nesvold, I.L., Fossa, S.D., \& Dahl, A.A. (2010). A study of body image in long-term breast cancer survivors. Cancer, 116 (15), 3549-57. doi: 10.1002/cncr.25251.

Fertig, D.L. (1997). Depression in patients with breast cancer: Prevalence, diagnosis, and treatment. The Breast Journal, 3, 292-302. doi: $10.1111 /$ i.15244741.1997.tb00184.x

Fobair, P., Stewart, S., Chang, S., D'Onofrio, C., Banks, P., \& Bloom, J. (2006). Body image and sexual problems in young women with breast cancer. Psycho-Oncology, 15, 579-594. doi: 10.1002/ pon.991

Ganz, P., Desmond, K., Leedham, B., Rowland, J., Meyerowitz, B., \& Belin, T. (2002). Quality of life in long-term, disease-free survivors of breast cancer: A follow-up study. Journal of the National Cancer Institute, 94, 39-49. doi:10.1093/inci/94.1.39

Han, W., Collie, K., Koopman, C., Azarow, J., Classen, C., Morrow, G., ...\& Spiegel, D. (2005). Breast cancer and problems with medical interactions: Relationships with traumatic stress, emotional self-efficacy, and social support. PsychoOncology, 14, 318-330. doi: 10.1002/pon.852

Hanson-Frost, M., Suman, V., Rumans, T., Dose, A., Taylor, M., Novotny, P., ...\& R., Evans, R. (2000). Physical, psychological and social well-being of women with breast cancer: The influence of disease phase. PsychoOncology, 9, 221-231. doi:10.1002/1099$1611(200005 / 06) 9: 3<221:: A \mid D$. PON456>3.0.CO;2-T

Helms, R., O'Hea, E., \& Corso, M. (2008). Body image issues in women with breast cancer. Psychology, Health \& Medicine, 13, 313-25. doi: 10.1080/13548500701405509.

Hopwood, P., Fletcher, I., Lee, A., \& Al Ghazal, S. (2001). A body image scale for use with cancer patients. European Journal of Cancer, 37, 189. 197.

Hox, J., \& Bechger, T.M. (1998). An introduction to structural equation modeling. Family Science Review, 17, 354-373. Retrieved from https://pdfs.semanticscholar.org/9e96/82af7abfe39145981 bb8feaf1 1a246b$71 \mathrm{fdb} . p \mathrm{df}$

Karademas, E., Karvelis, S., \& Argyropoulou, K. (2007). Stress-related predictors of optimism in breast cancer survivors. Stress and Health, 23, 161-168. doi: 10.1002/smi.1132 
Lam, W., \& Fielding R. (2007). Is self-efficacy a predictor of short-term post-surgical adjustment among Chinese women with breast cancer? Psycho-Oncology, 16, 651-659. doi: 10.1002/pon.1116

Leary, M. R., \& Baumeister, R. F. (2000). The nature and function of self-esteem: Sociometer theory. In M. P. Zanna (Ed.), Advances in experimental social psychology (pp. 1-62). New York, NY: Academic Press.

Lemieux, J., Maunsell, E., \& Provencher, L. (2008). Chemotherapy-induced alopecia and effects on quality of life among women with breast cancer: A literature review. Psycho-Oncology, 17, 317-328. doi: 10.1002/ pon. 1245

McClelland, S., Holland, K., \& Griggs, J. (2015). Quality of life and metastatic breast cancer: The role of body image, disease site, and time since diagnosis. Quality of Life Research, 24 (12), 2939-2943. doi: 10.1007/s $11136-015-1034-3$

Meyerowitz, B. (1980). Psychosocial correlates of breast cancer and its treatment. Psychological Bulletin, 87, 108-131. doi: 10.1037/0033-2909.87.1.108

Miller, S., Schnur, J., Weinberger-Litman, S., \& Montgomery, G. (2014). The relationship between body image, age, and distress in women facing breast cancer surgery. Palliative \& Supportive Care, 12, 363367. doi: 10.1017/S1478951513000321

Peralta, F. J., \& Sánchez, M. D. (2003). Relationship between self-concept and academic achievement in primary students. Electronic Journal of Research in Educational Psychology and Psycho-Pedagogy, 1, 95-120. Retrieved from http://www.investigacionpsicopedagogica.org/revista/articulos/1/english/ Art 1 7.pdf

Petronis, V., Carver, C., Antoni, M., \& Weiss, S. (2003). Investment in body image and psychosocial well-being among women treated for early stage breast cancer: Partial replication and extension. Psychology \& Health, 18, 1-13. doi: 10.1080/0887044021000020941

Poinsot, R., Brédart, A., This, P., De La Rochefordière, A., \& Dolbeault, S. (2005). The impact of hormone treatment on the quality of life and sexuality of breast cancer patients. Revue Francophone de PsychoOncologie, 4, 161-169. doi: 10.1007/s10332-0050077-z

Przezdziecki, A., Sherman, K., Baillie, A., Taylor, A., Foley, E., \& Stalgis-Bilinski, K. (2013). My changed body: Breast cancer, body image, distress and selfcompassion. Psycho-Oncology, 22, 1872-1879. doi: 10.1002/pon.3230

Raich, R. (2000). Imagen corporal: Conocer y valorar el propio cuerpo. Madrid, Spain: Pirámide.
Ridolfi, D., \& Crowther, J. (2013).The link between women's body image disturbances and bodyfocused cancer screening behaviors: A critical review of the literature and a new integrated model for women. Body Image, 10, 149-162. doi: 10.1016/i. bodyim.2012.11.003

Rogers, L., McAuley, E., Courneya, K., \& Verhulst, S. (2008). Correlates of physical activity self-efficacy among breast cancer survivors. American Journal of Health Behavior, 32, 594-603. doi: 10.5555/ aihb.2008.32.6.594.

Rosenberg, M. (1965). Society and adolescent selfimage. Princeton, NJ: Princeton University Press.

Schmid-Büchi, S., Halfens, R., Dassen, T., \& van den Borne, B. (2011). Psychosocial problems and needs of post-treatment patients with breast cancer and their relatives. European Journal of Oncology Nursing, 15, 260-266. doi: 10.1016/i.ejon.2009.11.001

Schmid-Büchi, S., Halfens, R., Müller, M., Dassen, T., \& van den Borne, B. (2013). Factors associated with supportive care needs of patients under treatment for breast cancer. European Journal of Oncology Nursing, 17, 22-29. doi: 10.1016/i.ejon.2012.02.003

Schover, L., Yetman, L., Tuason, L., Meiser, E., Esselsfym, C., Hermann, R., ...\& Dowden, R. (1995). Partial mastectomy and breast reconstruction. A comparison of their effects on psychosocial adjustment, body image, and sexuality. Cancer, 75, 54-64. doi: 10.1002/1097-0142(19950101)75:1<54::AID. CNCR2820750111>3.0.CO;2-I

Shavelson, R. J., \& Bolus, R (1992). Self-concept: The interplay of theory and methods. Journal of Educational Psychology, 74, 3-17.

Skrzypulec, V., Tobor, E., Drosdzol, A., \& Nowosielski, K. (2007). Biopsychosocial functioning of women after mastectomy. Journal of Clinical Nursing, 18 (4), 613-619. doi: 10.1111/i.13652702.2008.02476.x

Taylor, S., Lichtman, R., \& Wood, J. (1984). Attributions, beliefs about control, and adjustment to breast cancer. Journal of Personality and Social Psychology, 46, 489-502. doi: 10.1037/00223514.46 .3 .489

Tish, M. (2006). The influence of endocrine effects of adjuvant therapy on quality of life outcomes in younger breast cancer survivors. The Oncologist, 11, 96-110. doi: 10.1634/ theoncologist. 11 -2-96

Ussher, J., Perz, J., \& Gilbert, E. (2012). Changes to sexual well-being and intimacy after breast cancer. Cancer Nursing, 35, 456-465. doi: 10.1097/ NCC.Ob013e3182395401. 
Wong-Kim, E., \& Bloom, J. (2005). Depression experienced by young women newly diagnosed with breast cancer. Psycho-Oncology, 14, 564573. doi: 10.1002/pon.873

Yurek, D., Farrar, W., \& Andersen, B. (2000). Breast cancer surgery: Comparing surgical groups and determining individual differences in postoperative sexuality and body change stress. Journal of Consulting and Clinical Psychology, 68, 697-709. doi: 10.1037/0022-006X.68.4.697

Zachariae, R., Pedersen, C., Jensen, A., Ehrnrooth, E., Rossen, P., \& Von der Maase, H. (2003). Association of perceived physician communication style with patient satisfaction, distress, cancer-related self-efficacy, and perceived control over the disease. British Journal of Cancer, 88, 658-665. doi: 10.1038/si.bic.6600798
Zhao, W., Whu, J., Zhu, M., Fam, S., Si, S., \& Lian, H. (2001). Depression, anxiety and coping style in patients with breast cancer. Chinese Journal of Clinical Psychology, 9, 286-289.

Zigmond, A., \& Snaith, R. (1983). The hospital de pression and anxiety scale. Acta Psychriatrica Scandinavica, 67, 361-370. 